\title{
Dominant Weathering Profile Assessment of Kebo-Butak Volcanic Rocks in Gedangsari and Ngawen area, Yogyakarta, Indonesia
}

\author{
Fathan Hanifi Mada Mahendra, I Gde Budi Indrawan, and Sugeng Sapto Surjono* \\ Department of Geological Engineering, Faculty of Engineering, Universitas Gadjah Mada, Yogyakarta, Indonesia
}

\begin{abstract}
The Gedangsari and Ngawen area are predominantly composed of volcanic and volcaniclastic sequences distributed east-west direction of the northern parts of Southern Mountain. Massive tectonism and prolonge tropical climate in this region produce weathering profiles in varying thickness that inevitably affect geotechnical properties. This study aims to assess the dominant weathering profile of the lower part of the KeboButak Formation and evaluate the distribution of the discontinuity. In order to know the dominant weathering profile and discontinuity of the rocks, this study utilizes a total of 26 panels distributed in five stations that investigated the geological condition, weathering zones, joint distribution, and discontinuity characteristics. The result shows four types of dominant weathering profiles in the lower part of Kebo-Butak Formation that is dominant weathering profile A, B, C, and D. Profile A, B, C consists of a relatively identical weathering degree pattern of fresh, slightly, moderately, completely weathered zone with the variety of thicknesses. However, the weathering degree in profile D reached the residual soil degree controlled by more intensive joints. The fine-grained sedimentary rocks also tend to have smaller spacing, shorter persistence, and higher weathering degree of discontinuities than coarse-grained sedimentary rocks.
\end{abstract}

Keywords: Weathering profile $\cdot$ Discontinuity $\cdot$ Panel $\cdot$ Intensive joints $\cdot$ Kebo-Butak.

\section{INTRODUCTION}

Due to massive tectonic activity on Southern Mountain, including uplifting, faulting, and flexuring since Middle Pleistocene (van Bemmelen, 1949) and tropical climate, an intensive weathering of Kebo-Butak Formation were formed in Gedangsari and Ngawen subdistricts, Gunungkidul Regency, Special Province of Yogyakarta. Southern Mountain morphology in the research area shows the east-west direction of cuestas with foreslope in the north and backslope in the south (Surjono, 1995). According to Surono \& Sudarno (1992), the area is considered a mountainous structural area comprising interbedded sandstones, claystones, thin-bedded tuff in the upper part, and

\footnotetext{
${ }^{*}$ Corresponding author: S.S. SURJONO, Department of Geological Engineering, Universitas Gadjah Mada. Jl. Grafika 2 Yogyakarta, Indonesia. E-mail: sugengssurjono@ugm.ac.id
}

sandstone siltstones, claystone, shale, tuff, and agglomerate in the lower part of the KeboButak Formation. However, Surjono (1995) mentioned that the volcaniclastic successions in Southern Mountain cuesta's northern part are Kebo-Butak and Semilir Formations.

Heavy rains, hot and humid climatic conditions intensify the degree of weathering (Komoo, 1985) and the rock types, structures, topography, rate of erosion, and regional climate variation (Abad et al., 2014). Subsequently, this condition will have significant effects on the engineering works related to the weathered rock masses (Abad et al., 2014; Komoo, 1998; Moye, 1955; Raj, 2010; Ruxton \& Berry, 1957) as the rock mass characterization is compulsory for the preliminary stages of design and planning (Armaghani et al., 2014; Kalatehjari et al., 2014; Verma \& Singh, 2010). Previous researchers attempted to map the rock masses based on their 
weathering degrees that focused on granitic igneous rocks (Abad et al., 2014; Dearman, 1974; Zhao et al., 1994). As for the sedimentary rock, rock mass discontinuities and climatic conditions lead to significant weathering, causing the rock mass to deteriorate before approximately 50 to 100 years (Tating et al., 2015). This process will accelerate sedimentary rocks with finer grain size and the rapid formation of mechanical discontinuity after excavation (Tating et al., 2015). The purpose of this study was to assess the dominant weathering profiles in Kebo-Butak Formation in Ngawen and Gedangsari subdistricts by carrying out a thorough investigation of the geology, weathering degree, and discontinuity characteristics on five field stations. The study area represents a geological condition for the Southern Mountain area composed of volcanic and volcaniclastic rocks.

\section{Geological Setting}

The research area is part of the Southern Mountain region of Central Java, according to the subdivision of Java Physiography by van Bemmelen (1949). Regional geological structure within the basin is triggered by three factors, including the configuration of Sunda Shelf, Indian Plate Subduction to the north, and the movement of the Indian microcontinent to the north (Pulunggono \& Martodjojo, 1994). This tectonic influence on Java Island created three geological structure trends in the region: Northeast-Southwest (NE-SW), north-south (N-S), an east-west (E-W). Sudarno (1997) stated that the geological structure trend in the research area is dominated by NE-SW structures related to fault reactivation. Rahardjo (1983) and van Gorsel et al. (1989) stated that lithology within Kebo-Butak Formation comprises conglomeratic sandstone, claystone, and siltstone to be dated as Late Oligocene (N2N3) as determined by Sumarso (1975). Surjono (1995) also mentioned the interbedded sandstone and shale with the lava intercalation in the lower part of this formation. To the upper part of the successions, it is dominated by coarser sediments rich in tuff content.

\section{Research Method}

A total of 5 observation stations was selected in this study, covering the lower part of Kebo-
Butak Formation from Ngawen subdistricts in the eastern part to Gedangsari in the western part of the study area. These stations were mainly distributed in Benteng Wareng (Station $1 \& 2$ ), Tegalrejo (Station 3), and Tumpang Pondok (Station 4 \& 5), as seen in Figure 1 (red triangles). The study comprised the geological approach (lithology, geological structures, and topography), discontinuity analyses, and the weathering degree analyses based on the description of Ulusay \& Hudson (2007), discussing the procedure and field description to determine the weathering degree (see Table Table 1).

All rock masses of the Kebo-Butak Formation at the five stations were observed and analyzed for the dominant weathering profile, as seen in Figure 2. The identification and analyses of each weathering degree comprised the measurement of thickness, rock color, rock type, and their nature of discontinuity following the Ulusay \& Hudson (2007) classification (Table 1). In this study, sedimentary rock parameters such as grain size, sedimentary texture (notably rock matrix), structure, and composition were essential for the determination of each zone since the sedimentary property played a significant role in the deterioration process of rock weathering. The whole weathering zones found in the research area were from fresh rock to highly disintegrated rock or residual soil. These zones are fully explained below and have been illustrated based on their dominant types of weathering profiles.

\section{Results AND Discussion}

The result of the field observation and weathering analysis in each location is represented by several colors that can be seen in Figure 3 . Figure 3 shows the result of the weathering degree analysis in each location. Fresh rock zones (light green) were found in five research locations marked by the absence of matrix weathering with several minor discolorations along the rock discontinuity. These zones were dominated by the thick amalgamated tuffaceous sandstone facies found in all stations. Fresh rock zone thickness varied from $>10 \mathrm{~m}$ to $>5.5$ meters in two Bantengwareng stations to $<3 \mathrm{~m}$ in Tumpang Pondok and Tegalrejo. In Bantengwareng and Tumpang Pondok stations, rock 


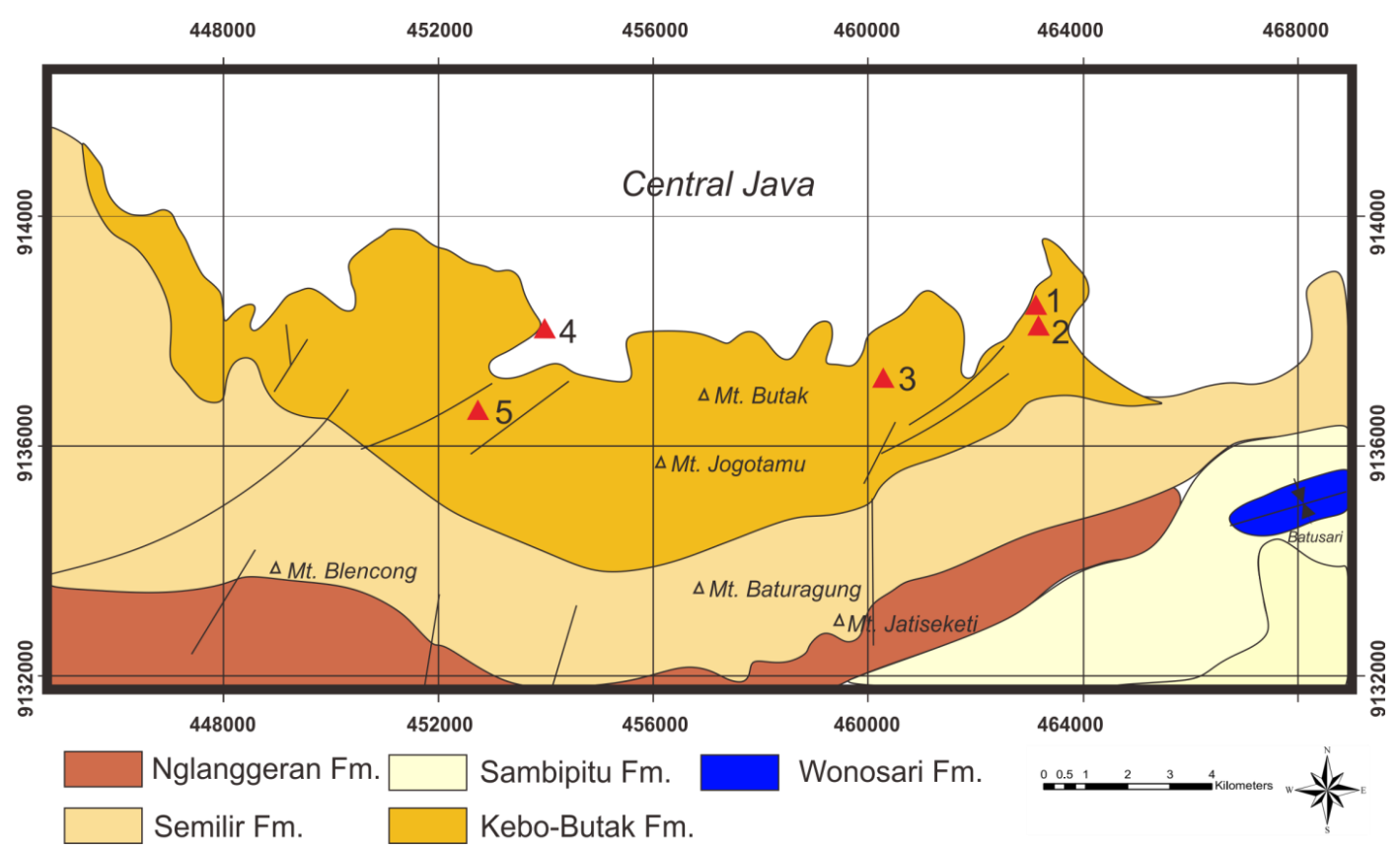

FIGURE 1. Distribution of outcrop locations within the study area of Kebo-Butak Formation (modified after Surono \& Sudarno., 1992).

TABLE 1. ISRM method to weathering degree analysis of rock mass (Ulusay \& Hudson, 2007).

\begin{tabular}{llc}
\hline Term & Description & Class \\
\hline Fresh (F) & $\begin{array}{l}\text { No visible sign of matrix weathering. Some rock discoloration may } \\
\text { be present along main discontinuities } \\
\text { Discoloration of rock indicates the beginning of rock matrix } \\
\text { Weathering and along the discontinuity surfaces. All rock matrices } \\
\text { can be discolored by weathering and be slightly softer externally } \\
\text { than in sound conditions. }\end{array}$ & II \\
Moderately Weathered & $\begin{array}{l}\text { Lower than half of the rock matrix is decomposed or disintegrated } \\
\text { into soil conditions. As a result, sound or discolored rock is present } \\
\text { forming discontinuous zones or as corestones. }\end{array}$ & III \\
(MW) & $\begin{array}{l}\text { More than half of the rock matrix is decomposed or disintegrated to } \\
\text { soil conditions. As a result, sound or discolored rock is present } \\
\text { forming discontinuous zones or as corestones. }\end{array}$ & IV \\
Highly Weathered (HW) & $\begin{array}{l}\text { All rock matrices are decomposed or disintegrated into soil } \\
\text { conditions. However, the original structure of rock mass is } \\
\text { commonly preserved. }\end{array}$ \\
$\begin{array}{l}\text { Completely Weathered } \\
\text { (CW) }\end{array}$ & $\begin{array}{l}\text { All rocks are transformed into soil. The geological structure of rock } \\
\text { mass is destroyed. There is a tremendous volume variation but no } \\
\text { significant soil transport. }\end{array}$ & VI \\
Residual Soil (RS) & V & \\
\hline
\end{tabular}



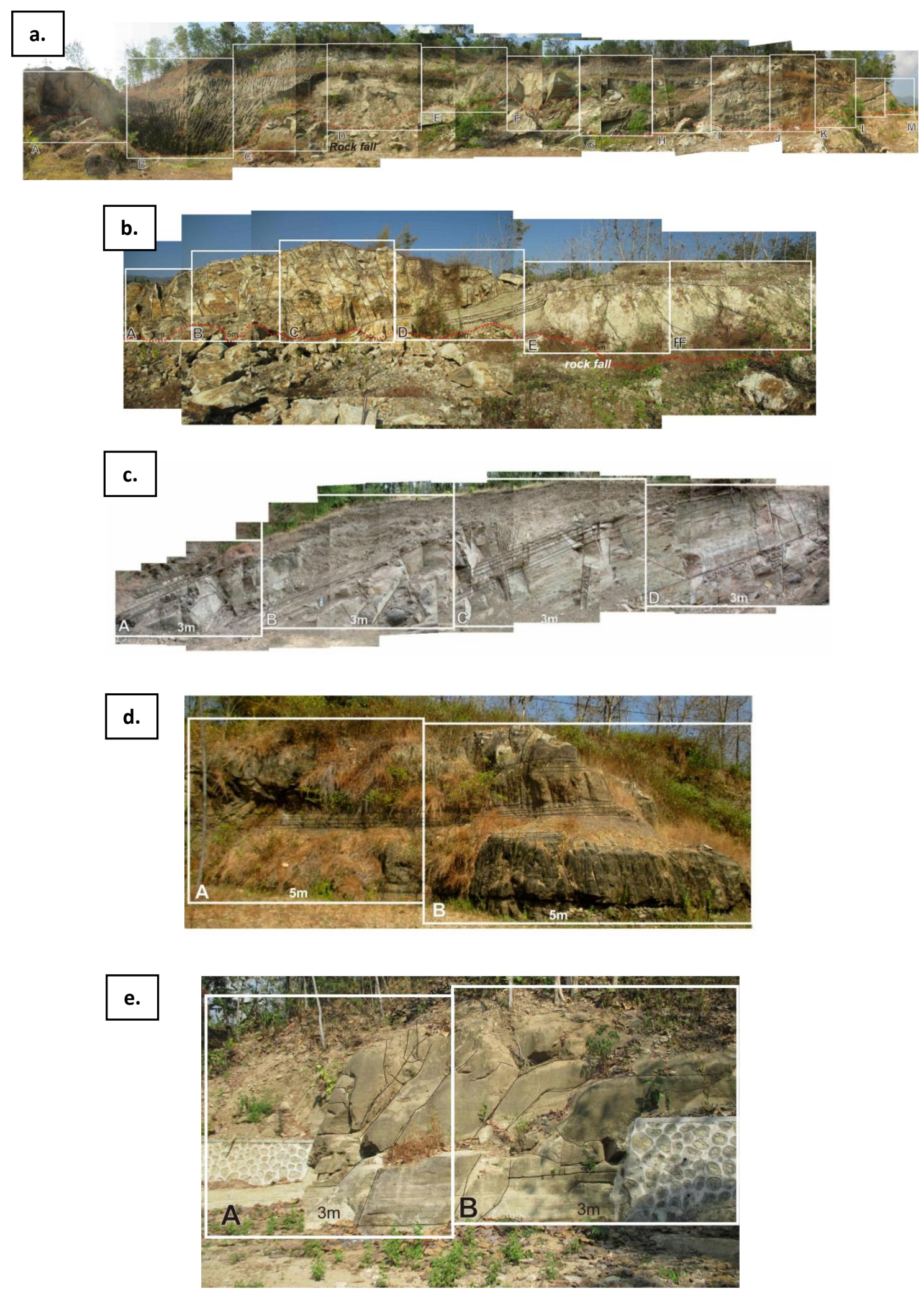

FIGURE 2. Overview of outcrop panels in the study area: a) Station 1, Bantengwareng showing 5-meterpanels from A to $M$ with the dimension $\mathrm{L}=65 \mathrm{~m} / \mathrm{H}=21 \mathrm{~m}, \mathrm{~b}$ ) Station 2, Bantengwareng showing 5-meterpanels from $A$ to $F$ with the dimension $\mathrm{L}=30 \mathrm{~m} / \mathrm{H}=4 \mathrm{~m}, \mathrm{c}$ ) Station 3, Tegalrejo showing 3-meter-panels from $\mathrm{A}$ to $\mathrm{D}$ with the dimension of $\mathrm{L}=16 \mathrm{~m} / \mathrm{H}=3.5 \mathrm{~m}$, d) Station 4 Tumpang Pondok showing a 5-meter panel of A \& B with the dimension $\mathrm{L}=10 \mathrm{~m} / \mathrm{H}=5 \mathrm{~m}$, e) Station 5 Tumpang Pondok showing 3-meter-panels of A \& B with the dimension of $\mathrm{L}=6 \mathrm{~m} / \mathrm{H}=3 \mathrm{~m}$. Note: white boxes indicate panels of each location, dashed red line indicates the boundary between the rockfall debris and non-failure rock mass. 
matrix weathering of a slightly weathered zone could be observed in fine-grained sedimentary rocks composing tuff, very fine-grained sandstone, and claystone facies. This sequence was characterized by the reddish-greenish brown to the gray color of rock with approximately two discontinuities sets. The fine-grained material had probably accelerated the weathering process creating erratic weathering degrees in this location. This condition might occur due to its position between a relatively more resistant rock supported by the study done by Tating et al. (2015). The slightly weathered (gray) zone was characterized by the rock matrix weathering and rock matrix discoloration with a total thickness of $0.5-3 \mathrm{~m}$.

The moderately weathered zone (light brown) was characterized by less than half of the disintegrated rock matrix to the soil. In Tegalrejo and Tumpang Pondok stations, this zone was characterized by corestones in several panels. The thickness of this zone ranged between $2-8.5 \mathrm{~m}$. In the research area, the moderately weathered zone had brownish-gray color, discoloration occurred on the post-excavated rock, particularly in the Bantengwareng station.

The highly weathered zone (dark brown) was present in all stations within the research area characterized by more than half of the disintegrated rock matrix to soil condition. The discoloration was present along the rock with a reddish-brown color. The thickness of this zone varied from $0.5-3 \mathrm{~m}$. At the same time, the wholly weathered zone was only present in Bantengwareng and Tumpang Pondok (locations 1 and 5) and was absent in locations 2, 3 and 4. A moderate yellowish-brown color characterized this zone with $0.5-1 \mathrm{~m}$ thickness. Generally, the highly and completely weathered zones were mainly found in fine-grained sediments such as tuff, siltstone, and claystones rich in volcanic glass and feldspar (Surjono, 1995). These two minerals are the key minerals that accelerate weathering process of rocks through their structural defects, particularly at the boundaries of twinned and untwinned domains (Wilson, 2004). This circumstance can trigger a faster weathering process in these lithologies than other lithologies with less abundance of feldspar and volcanic glass.

Based on this research, residual soil in Tegal- rejo (location 3) reaches a thickness of less than $1 \mathrm{~m}$. This zone was characterized by brown color, where all rocks were transformed into soil. During the field observation, the soil was also identified in Location 5 in Tumpang Pondok with $<1 \mathrm{~m}$ thickness. However, this soil was neglected due to the farming activity above this zone that has probably altered the original residual soil.

Figure 4 exhibits four dominant weathering profiles found in the research area. Generally, all of the dominant profiles indicated an identical pattern of ideal weathering from fresh rock, slightly weathered, highly weathered, to completely weathered zone, respectively. The dominant weathering type $\mathrm{A}, \mathrm{B}$, and $\mathrm{C}$ are commonly found in three locations $(1,2,4)$ which have a regularly fresh, moderately, highly, and completely weathered from the bottom to top of the outcrop. Meanwhile, the weathering type $\mathrm{D}$ was only identified in location 3 (Tegalrejo). The evidence of physical or chemical weathering in locations $1,2 \& 4$, such as the occurrence of spheroidal weathering, is not found. In these locations, the fresh rock is visually examined. It shows a relatively light to moderate grey color showing a complete unweathered mineralogical component having an average thickness of $>5.5$ meters to $>10$ meters. The discontinuity separation in this zone is 6 to 7 meters with yellowish-grey color along the discontinuity surface. The slightly weathered are characterized by reddish-greenish-brown discoloration along the discontinuity orientation having the intermediate thickness zone of $0.5-3 \mathrm{~m}$, particularly in locations 1, 2 \& 4 . Finally, the highly and completely weathered zone is identified in almost all locations characterized by moderate yellowish-brown color and predominantly composed of fine-grained sediments such as tuff, silt, and very fine-grained sandstones.

Based on the discontinuity analysis, the residual soil was only present in station 3 Tegalrejo. Discontinuity in this station has spacing $5-20 \mathrm{~cm}$ with shorter persistence, around 30$100 \mathrm{~cm}$ (as seen in Figure $3 \mathrm{c}$ panel C). Smaller discontinuity spacing has increased the weathering surface on the rock and created a more intense potential for rock failure and weathering. This circumstance resulted in a more massive weathering process creating a residual 

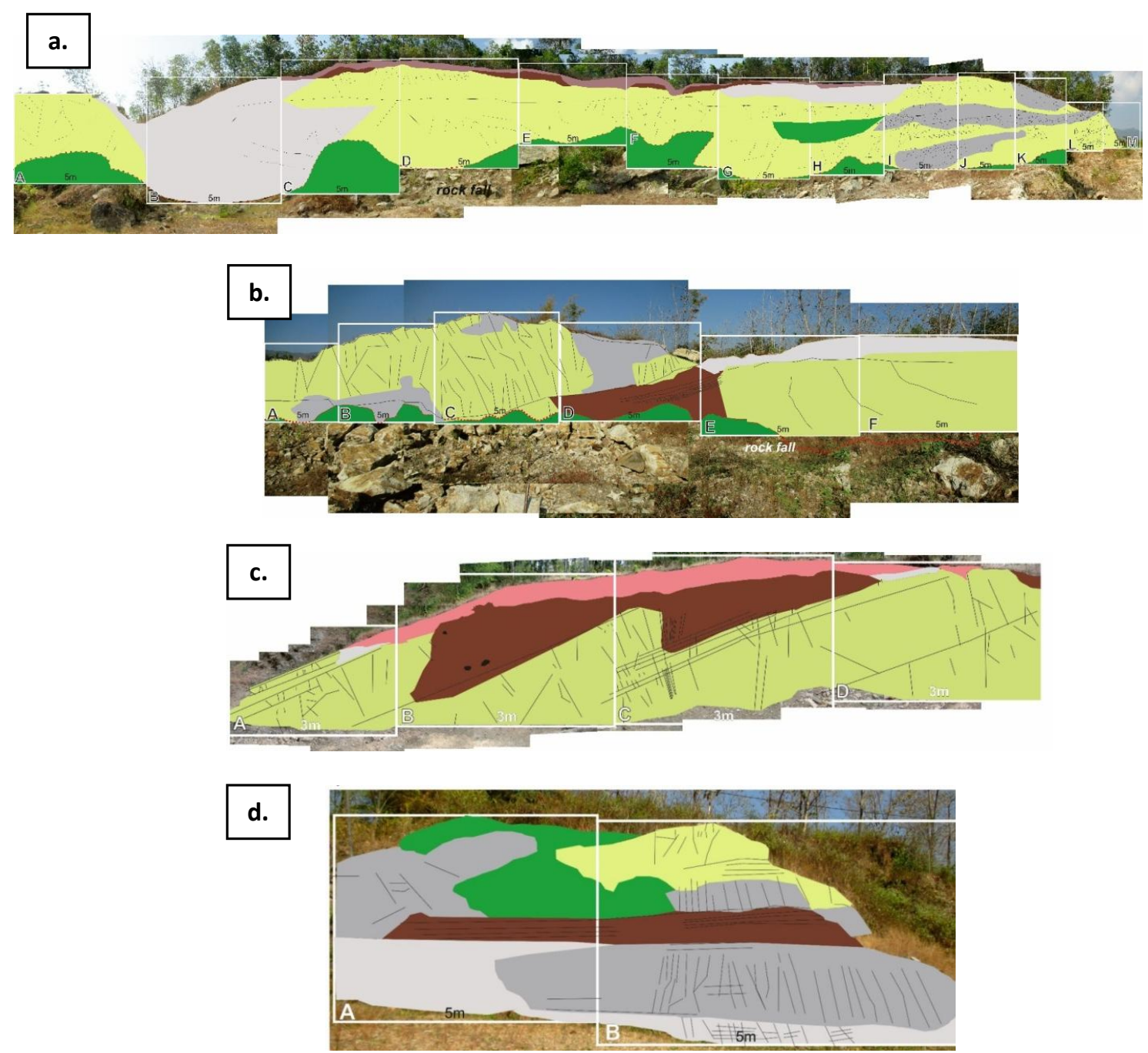

e.

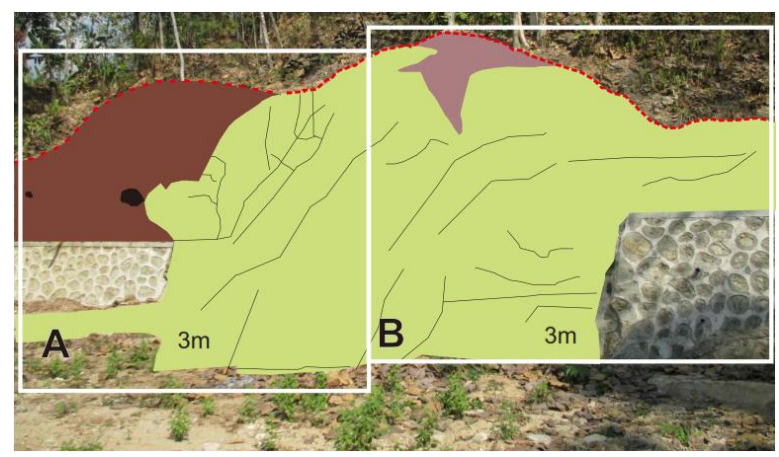

Completely weathered

Highly weathered

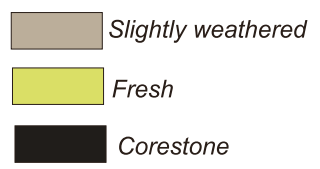

Covered by vegetation and rockfall

Moderately weathered

Corestone

Diskontinuitas

Rockfall - Main outcrop Boundary

FIGURE 3. Overview of dominant weathering profile in the study area: a) Station 1 Bantengwareng predominantly showing fresh rock zone to slightly weathered zone from panel A to $M, b$ ) Station 2, Bantengwareng predominantly showing fresh rock to the slightly weathered zone from panel A to D, c) Station 3, Tegalrejo predominantly showing fresh and highly weathered zone from panel A to D, d) Station 4, Tumpang Pondok predominantly showing slightly weathered zone from panel A to B, e) Station 5, Tumpang Pondok showing predominantly fresh rock zone to highly weathered zone from panel A to B. 


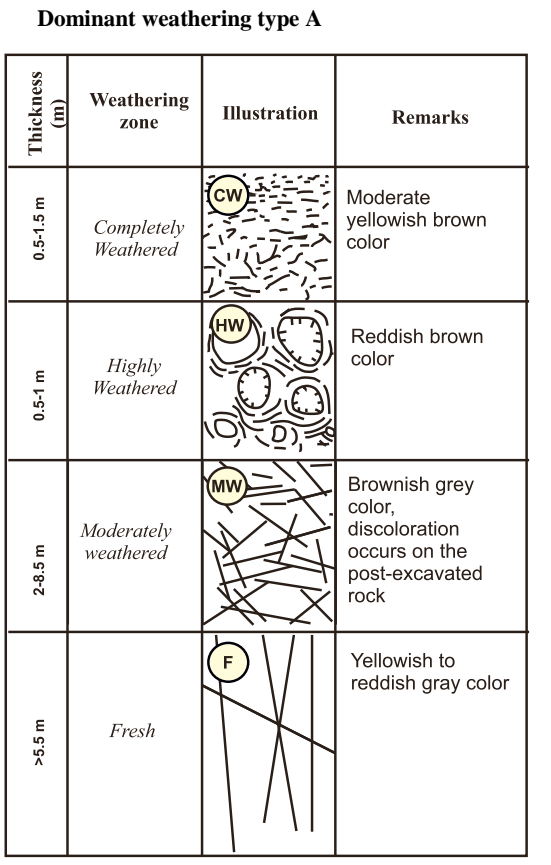

Dominant weathering type $\mathrm{C}$

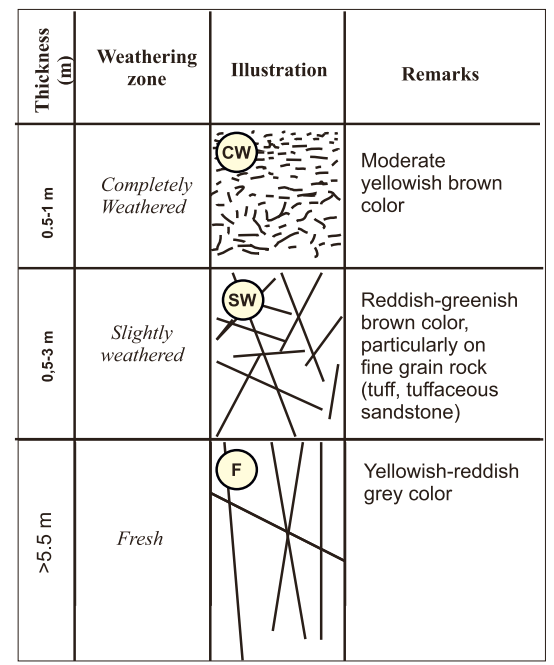

Dominant weathering type B

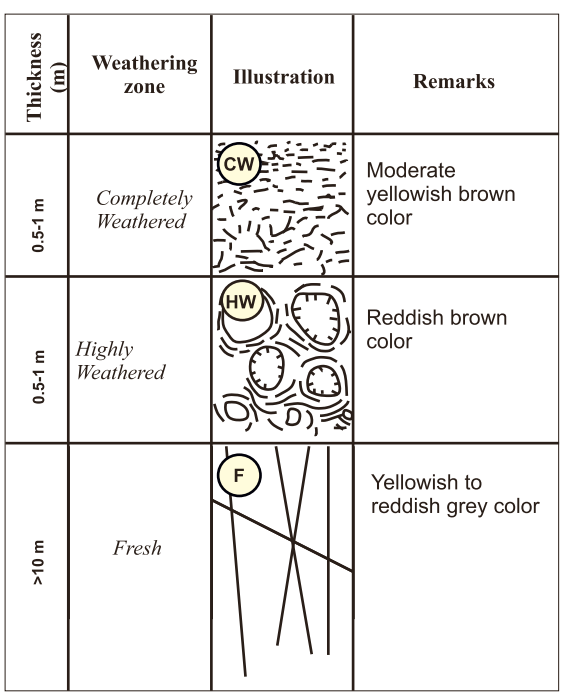

Dominant weathering type D

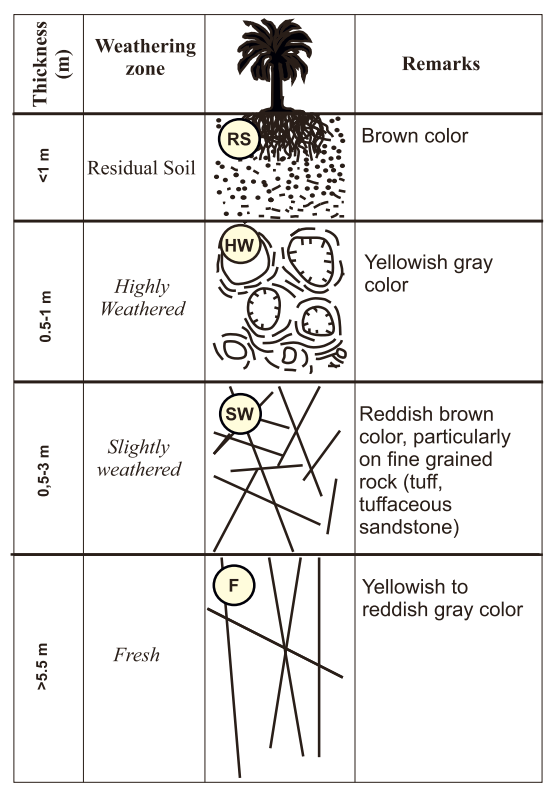

FIGURE 4. Dominant weathering profile that developed within the study area (illustration reference from Abad et al., 2014). 
soil layer with a $30-40 \mathrm{~cm}$ thickness. In addition, several spheroidal weathering blocks are also found in this location due to the increasing intensity of weathering surface. In comparison, the Bantengwareng (locations 1 \& 2) and Tumpang Pondok station (locations 4 and 5) had a relatively more significant spacing (ranging from $50-400 \mathrm{~cm}$ ) and longer persistence (1$4.5 \mathrm{~m})$. These differences of discontinuity properties have led to a significant effect on decreasing weathering surface on rock's successions in the research location.

\section{CONCLUSION}

This study infers that four proposed dominant weathering profiles in the research area named profile A, B, C, D. The interpretation are based not only on the ISRM (2007) classification but also on the thorough investigation of the sedimentary rock properties. The fine-grained sedimentary rocks with a high abundance of feldspar and volcanic glass tend to experience a rapid weathering process compared to other rocks with a low abundance of feldspar, volcanic material, with a relatively coarser grain. Furthermore, the smaller spacing and shorter persistence controlled by the geological structures played a significant role in the higher weathering degree in the Kebo-Butak Formation. From all locations, location 3 (Tegalrejo) shows a more intensive discontinuity having the $5-20 \mathrm{~cm}$ separation and $30-100 \mathrm{~cm}$ and has led to massive weathering, creating a residual soil layer in this location. Meanwhile, location $1 \& 2$ in Bantengwareng has a relatively shorter separation and longer persistence with less intense weathering.

\section{ACKNOWLEDGEMENTS}

The authors would like to thank master student colleagues who had contributed and were involved in the data acquisition during the field activity. Among them are Mayda Citra, Heri Purwanto, and Samuri. We are also grateful for the supervision of every expert to make this research better, including M. Agni and Thema Arrisaldi for the field analysis.

\section{REFERENCES}

Abad, S. A. N. K., Mohamad, E., \& Komoo, I. (2014)

Dominant weathering profiles of granite in south- ern Peninsular Malaysia. Engineering Geology, 183, 208-215.

Armaghani, D. J., Hajihassani, M., Mohamad, E. T., Marto, A., \& Noorani, S. (2014) Blasting-induced flyrock and ground vibration prediction through an expert artificial neural network based on particle swarm optimization. Arabian Journal of Geosciences, 7(12), 5383-5396.

Dearman, W. (1974) Weathering classification in the characterisation of rock for engineering purposes in British practice. Bulletin of the International Association of Engineering GeologyBulletin de 1'Association Internationale de Géologie de l'Ingénieur, 9(1), 33-42.

Gumede, T. (2007) Measurement of typical joint characteristics in South African gold mines and the use of these characteristics in the prediction of rock falls. Journal of the Southern African Institute of Mining and Metallurgy, 107(5), 335-344.

Kalatehjari, R., Ali, N., Kholghifard, M., \& Hajihassani, M. (2014) The effects of method of generating circular slip surfaces on determining the critical slip surface by particle swarm optimization. Arabian Journal of Geosciences, 7(4), 1529-1539.

Komoo, I. (1985) Engineering properties of weathered rock profiles in Peninsular Malaysia: Institution of Engineers Malaysia.

Komoo, I. (1998) Deep weathering: major cause of slope failure in wet tropical terrain. Paper presented at the Engineering Geology: A global view from the Pacific Rim.

Moye, D. (1955) Engineering geology for the Snow Mountain schema. Jour. Institution of Engineers, Australia, 27, 281-299.

Pulunggono, A., \& Martodjojo, S. (1994) Perubahan tektonik paleogen-neogen merupakan peristiwa tektonik terpenting di Jawa. Proc. Geologi dan Geoteknik Pulau Jawa, Yogyakarta, h, 37-49.

Rahardjo, W. (1983) Paleoenvironmental Reconstruction of the Sedimentary Sequence of The Baturagung Escarpment Gunung Kidul Area Central Java. Proceedings PIT XII IAGI. Yogyakarta, 6-8.

Raj, J. K. (2010) Soil-moisture retention characteristics of earth materials in the weathering profile over a porphyritic biotite granite. Am. J. Geosci, $1(1), 12-20$.

Ruxton, B. P., \& Berry, L. (1957) Weathering of granite and associated erosional features in Hong Kong. Geological Society of America Bulletin, 68(10), 1263-1292.

Şen, Z. (2014) Rock quality designation-fracture intensity index method for geomechanical classification. Arabian Journal of Geosciences, 7(7), 2915-2922.

Sudarno, I. (1997) Petunjuk Adanya Reaktifasi Sesar di Sekitar Aliran Sungai Opak, Perbukitan Jiwo 
dan Sisi Utara Kaki Pegunungan Selatan. Media Teknik, 19(1997).

Sumarso, T. I. (1975) Contribution to the Stratigraphy of the Jiwo Hills and Their Southern Surroundings (Central Java).

Surjono, S.S. (1995) Geologi Daerah Baturagung dan Sekitaranya, Kabupaten Gunungkidul, Daerah Istimewa Yogyakarta. Tugas Akhir Tipe Pemetaan di Jurusan Teknik Geologi FT UGM. Unpublished.

Surono, B. T., \& Sudarno, I. (1992) Peta Geologi Lembar Surakarta-Giritontro, Jawa. Bandung: Pusat Penelitian dan Pengembangan Geologi.

Tating, F., Hack, R., \& Jetten, V. (2015) Weathering effects on discontinuity properties in sandstone in a tropical environment: case study at Kota Kinabalu, Sabah Malaysia. Bulletin of Engineering Geology and the Environment, 74(2), 427-441.

Ulusay, R. \& Hudson, J. (2007) The complete ISRM suggested methods for rock characterization, test- ing, and monitoring. ISRM Turkish National Group, Ankara, Turkey.

Van Bemmelen, R. (1949) The geology of Indonesia (Vol. 1A). Nederland: The Hague, Martinus Nijhoff.

Van Gorsel, J. H., Kadar, D., \& Mey, P. H. (1989) Central Java Fieldtrip.

Verma, A. K., \& Singh, T. (2010) Modeling of a jointed rock mass under triaxial conditions. Arabian Journal of Geosciences, 3(1), 91-103.

Wilson, M. J. (2004) Weathering of the primary rockforming minerals: processes, products and rates. Clay Minerals, 39(3), 233-266.

Zhao, J., Broms, B., Zhou, Y., \& Choa, V. (1994) A study of the weathering of the Bukit Timah granite part A: review, field observations and geophysical survey. Bulletin of the International Association of Engineering Geology-Bulletin de l'Association Internationale de Géologie de l'Ingénieur, 49(1), 97-106. 